\title{
Trends in Forage Fish Populations in Northern Hudson Bay since 1981, as Determined from the Diet of Nestling Thick-Billed Murres Uria lomvia
}

\author{
ANTHONY J. GASTON, ${ }^{1}$ KERRY WOO ${ }^{2}$ and J. MARK HIPFNER ${ }^{3}$
}

(Received 7 June 2002; accepted in revised form 26 October 2002)

\begin{abstract}
Trends in the composition of nestling thick-billed murre diets were analyzed for the period 1980-2002 on the basis of observations of food delivered to nestlings at two breeding colonies in northern Hudson Bay. The incidence of arctic cod, sculpins, and benthic Zoarcidae decreased and the incidence of capelin and sandlance increased over the period considered. Arctic cod fell from a mean of $43 \%$ of deliveries in the mid-1980s to $15 \%$ in the late 1990s; benthic species (zoarcids and sculpins) fell from $36 \%$ to $15 \%$, while capelin increased from $15 \%$ to $50 \%$ over the same period. July ice cover in Hudson Bay approximately halved during 1981-99. We suggest that the observed changes in diet composition reflect changes in the relative abundance of the fish species involved and that the decline in arctic cod and increase in capelin and sandlance were associated with a general warming of Hudson Bay waters, the result of ongoing climate change in the region.
\end{abstract}

Key words: Hudson Bay, forage fish trends, Uria lomvia, nestling diet, Mallotus villosus, Boreogadus saida, Ammodytes spp., Zoarcidae

RÉSUMÉ. On a analysé les tendances dans la composition du régime alimentaire des oisillons du guillemot de Brünnich au cours de la période allant de 1980 à 2002, d'après les observations de l'apport de nourriture aux oisillons à deux colonies de nidification dans le nord de la baie d'Hudson. On a assisté, au cours de cette période, à une baisse de la fréquence de la morue polaire, du chabot et des zoarcidés benthiques, et à une augmentation de celle du capelan et du lançon. La morue polaire a chuté d'une moyenne représentant $43 \%$ de l'apport au milieu des années 1980 à $15 \%$ à la fin des années 1990; les espèces benthiques (zoarcidés et chabots) ont chuté de 36 à $15 \%$, tandis que le capelan a augmenté de 15 à $50 \%$ au cours de la même période. En juillet, le manteau glaciel dans la baie d'Hudson a diminué de moitié environ entre 1981 et 1999. On suggère que les changements observés dans la composition du régime alimentaire sont un reflet des changements dans l'abondance relative des espèces de poissons concernées et que le déclin de la morue polaire et l'augmentation du capelan et du lançon étaient associés à un réchauffement général des eaux de la baie d'Hudson, réchauffement qui résulte du changement climatique que connaît actuellement la région.

Mots clés: baie d'Hudson, tendances des poissons proies, Uria lomvia, régime alimentaire des oisillons, Mallotus villosus, Boreogadus saida, Ammodytes spp., zoarcidés

Traduit pour la revue Arctic par Nésida Loyer.

\section{INTRODUCTION}

Over recent decades, climate change has been shown to be influencing many biological systems (Bradley et al., 1999; Brown et al., 1999; Crick and Sparks, 1999; Hughes, 2000; Inouye et al., 2000). Because greenhouse gas-induced global warming is predicted to be most intense at high latitudes (Ledrew, 1993; Intergovernmental Panel on Climate Change, 1995; Cattle and Crossley, 1996), we can anticipate that high-latitude environments may be among the first to show the results of climate change (Brown, 1991; Boyd and Diamond, 1994; Boyd and Madsen, 1997). For example, Northern Hemisphere sea ice has receded in thickness and extent in recent decades, and the extent of the retreat appears to be well beyond that expected as a result of natural variation in climate (Vinnikov et al., 1999).
Earlier sea-ice breakup has already been demonstrated to have caused earlier laying and higher colony attendance in thick-billed murres Uria lomvia (Gaston and Hipfner, 1998) in northern Hudson Bay, and it has caused deterioration in female body condition among polar bears Ursus maritimus in western Hudson Bay (Stirling et al., 1999).

Colonial seabirds can be useful indicators of changes in marine ecosystems. The aggregation of large numbers of birds at predictable localities during the breeding season means that data can be obtained that integrate oceanic effects taking place over a wide area around the colony (Boersma, 1978; Cairns, 1992; Montevecchi, 1993; Montevecchi and Myers, 1996, 1997). Seabirds feeding on commercially fished species have been shown to be sensitive to changes in local fish stocks (Uttley et al., 1989; Hamer et al., 1993; Bertram and Kaiser, 1993; Montevecchi

\footnotetext{
${ }^{1}$ CWS, National Wildlife Research Centre, 1125Colonel By Drive(Raven Road), Ottawa, Ontario K1A 0H3, Canada; tony.gaston@ec.gc.ca

${ }^{2}$ Department of Biology, University of Ottawa, Ottawa K1N 6N5, Canada

${ }^{3}$ Canadian Wildlife Service, Pacific and Yukon Region, 5412 Robertson Road, RR \#1, Delta, British Columbia V4N 3N2, Canada

(C) The Arctic Institute of North America
} 
and Myers, 1997). Here, we use data collected on the diet of an Arctic-breeding seabird, the thick-billed murre, to infer changes in fish populations in northern Hudson Bay over the past two decades. Further, we assess the likelihood that the observed changes are related to climatic change in the Hudson Bay region.

The thick-billed murre is a circumpolar species that breeds only in the Arctic and Subarctic, wintering in the northernmost ice-free areas and feeding almost entirely in waters at less than $8^{\circ} \mathrm{C}$ throughout the year (Tuck, 1961; Gaston and Hipfner, 2000). Thick-billed murres forage underwater to depths of $200 \mathrm{~m}$ (Croll et al., 1992; Falk et al., 2000), feeding on small fishes, squid, and large zooplankton (Gaston and Bradstreet, 1993; Gaston and Hipfner, 2000). Nestlings are fed by their parents at the breeding site for $15-30$ days before departing to sea. Food destined for nestlings is carried, held externally in the parent's bill, from the feeding grounds to the breeding colony. Hence, it arrives at the colony more or less undamaged and readily identifiable. In this paper, we report on trends in the composition of food fed to nestlings in the region of northern Hudson Bay since 1981. We compare these trends with trends in ice cover for Hudson Bay over the same period.

\section{METHODS}

Observations were made at a breeding colony of about 30000 pairs on Coats Island, Nunavut, Canada, in the centre of northern Hudson Bay (Gaston et al., 1993, 1994) in 1981 and annually from 1984 to 2002. Additional data were available from another colony of thick-billed murres at Digges Island, Nunavut, situated at the NW tip of the Ungava Peninsula (Fig. 1), for 1980-82, 1992, and 1999 (for details of this colony see Gaston et al., 1985). Visual identifications of fish delivered to nestlings were used. Only a single prey item is delivered on most provisioning visits, but occasionally two to five small items may be delivered, either larval fish or large zooplanktonic crustacea. When more than one individual was delivered, meals always consisted of a single prey type. We have used the meal as the unit of measure: prey frequencies are estimated as the proportion of all meals delivered in which the prey was identified as belonging to one of the following categories: Arctic cod Boreogadus saida, capelin Mallotus villosus, sandlance Ammodytes spp., 'zoarcids' (Stichaeus, Eumesogrammus, Leptoclinus, Gymnelus, or Pholis), sculpin (Triglops, Gymnocanthus or Myoxocephalus), invertebrate (squid Gonatus fabricii, shrimp or amphipod Parathemisto). For purposes of illustration, the two benthic groups, sculpins and zoarcids, were combined in Figures 2 and 3.

As cod made up over $40 \%$ of diet items in eight of 19 years, and as this species appears to be a preferred diet item of thick-billed murres throughout much of their range in Canada (Gaston and Nettleship, 1981; Gaston and

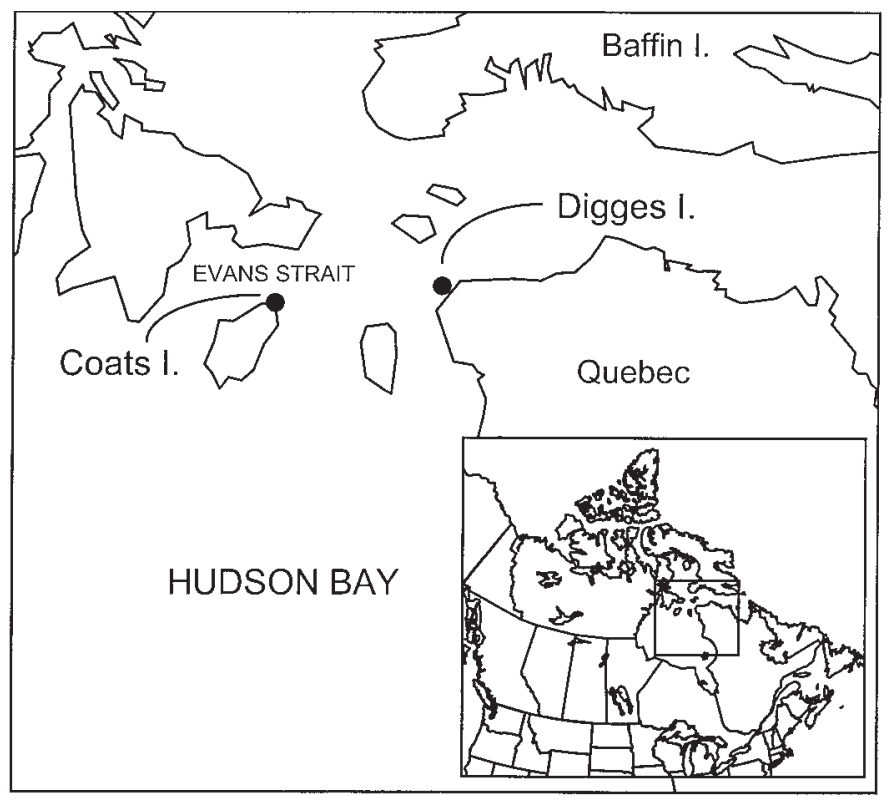

FIG. 1. Location of study sites.

Bradstreet, 1993; Gaston and Hipfner, 2000), we also examined the representation of other taxa, once arctic cod had been removed (referred to as "sample minus cod"). Trends over years were tested for significant departure from random using the regression routine of STATISTICA (Statsoft Inc., 2001), with percentage data arcsin transformed. Fish nomenclature follows Hunter et al. (1984).

Observations of prey delivered derived from three sources: continuous feeding watches, during which observers identified fish delivered to a predetermined sample of chicks ( $25-40$ chicks) over a fixed time period, usually a multiple of $24 \mathrm{~h}$; opportunistic observations of fish deliveries seen in the course of other work at the colony; and observations of fish discarded on breeding ledges. During 1981-87, the majority of records were opportunistic observations, or fish discarded on breeding ledges. From 1990 onwards, the majority were observed during systematic watches. Discarded fish were collected and preserved for subsequent voucher identification, which was performed by the staff of the Canadian Museum of Nature (D. McAllister, B. Coad, C. Renaud). Because the proportion of different prey species changed over the course of the season in a few years, and as observations in early years were confined to the latter part of the chickrearing period, we have confined our analysis to the period 1-15 August, which corresponds approximately to the period after the majority of chicks had hatched, but before large-scale departure had begun.

Data on ice conditions in Hudson Bay from 1981 to 1999, based on ice distribution maps for 15 July each year, were supplied by the Canadian Ice Service of Environment Canada. The chosen date represents conditions immediately before the start of chick rearing, as hatching commenced about 18 July in most years. The statistic used was the extent $\left(\mathrm{km}^{2}\right)$ of ice cover greater than 10\%. The summer 
TABLE 1. Regression of proportions of different taxa in the diet of thick-billed murre nestlings on year: 1981, 1984-2002.

\begin{tabular}{|c|c|c|c|c|c|c|c|c|}
\hline \multirow[t]{2}{*}{ Taxon } & \multicolumn{4}{|c|}{ Whole sample } & \multicolumn{4}{|c|}{ Sample minus cod } \\
\hline & $\mathrm{R}^{2}$ & $\mathrm{~F}_{1,18}$ & $p$ & Beta & $\mathrm{R}^{2}$ & $\mathrm{~F}_{1,18}$ & $p$ & Beta \\
\hline Cod & .44 & 15.84 & $<.001$ & -0.68 & & & & \\
\hline Sculpin & .20 & 5.62 & .03 & -0.49 & .42 & 14.63 & .001 & -0.67 \\
\hline 'Benthic' spp. & .36 & 11.57 & .003 & -0.63 & .53 & 22.22 & $<.001$ & -0.74 \\
\hline Capelin & .51 & 20.43 & $<.001$ & +0.73 & .40 & 13.44 & .002 & +0.65 \\
\hline Sandlance & .31 & 9.71 & .006 & +0.59 & .14 & 4.06 & .06 & \\
\hline
\end{tabular}

of 1992 was exceptionally cold because of the eruption of Mount Pinatubo (McCormick et al., 1995), a phenomenon that had striking consequences for Arctic-breeding birds (Ganter and Boyd, 2000). Consequently, we have repeated some analyses omitting data for 1992.

\section{RESULTS}

\section{Ice Cover}

Ice cover in Hudson Bay in mid-July declined significantly between 1981 and $1999\left(\mathrm{~F}_{(1,17)}=9.85, \mathrm{R}^{2}=0.33\right.$, $p=0.006)$. When we removed 1992, the year of the Mount Pinatubo eruption, the value of $\mathrm{R}^{2}$ increased to $0.52\left(\mathrm{~F}_{(1,16)}\right.$ $=19.06)$.

\section{Coats Island}

A mean 245 meals (range 51-503) delivered to thickbilled murre nestlings were identified annually. The proportion of arctic cod, sculpins, and zoarcids in chick diets declined significantly during the period of the study, while the proportion of capelin and sandlance rose significantly (Table 1, Fig. 2). The proportion of invertebrates remained constant. Consequently, the benthic species combined declined significantly. When 1992 was omitted, the $\mathrm{R}^{2}$ value for the proportion of arctic cod increased to 0.50 , and that for capelin to 0.54 , while those for zoarcids and sandlance remained unchanged.

Once cod were removed from the sample, the proportion of both zoarcids and sculpins declined significantly over time, while the proportion of capelin rose significantly (Table 1). To determine whether the trend in capelin in the sample without cod was related to the proportion of cod in the original sample once the effect of year was removed, both year and original percentage of cod were entered in a forward stepwise multiple regression analysis, excluding 1992. In this analysis, the proportion of capelin in the sample minus cod was significantly related to the proportion of cod in the original sample $\left(\mathrm{R}^{2}=0.52, \mathrm{~F}_{(2,16)}=10.82\right.$, $p=0.001)$ : when the original sample contained more cod, capelin formed a smaller proportion of the remainder $(\beta=$ $-0.52, \mathrm{t}=-2.21, p=0.04)$. The effect of year was insignificant $(\beta=0.28, t=1.19)$. The proportion of zoarcids in the sample minus cod was positively correlated with the proportion of cod in the original sample $(\beta=+0.82)$. Again, the effect of year was insignificant $\left(\beta=0.20, \mathrm{t}_{16}=-1.50\right)$ when "year" and "original percentage of cod" were entered as independent variables in a forward stepwise multiple regression analysis $\left(\mathrm{R}^{2}=0.67, \mathrm{~F}_{(2,16)}=19.29, p<0.001\right)$.

Comparing the earliest and latest consecutive four-year periods (1984-87, 1998-2002), cod fell from a mean of $43 \%$ to $15 \%$ of the annual deliveries and benthic species (zoarcids and sculpins) from $36 \%$ to $15 \%$, while capelin increased from a mean of $15 \%$ to $51 \%$ and sandlance from $3 \%$ to $15 \%$ (Fig. 3 ).

The proportions of both cod and capelin observed were significantly correlated with ice cover $\left(\operatorname{cod} \mathrm{R}^{2}=0.32, \mathrm{~F}_{(1,15)}\right.$ $=8.45, p=0.011, \beta=0.60 ;$ capelin $\mathrm{R}^{2}=0.28, \mathrm{~F}_{(1,15)}=7.07$, $p=0.020, \beta=-0.57$ ); no other taxa were significantly correlated with ice cover. However, in multiple regression analyses, ice conditions did not add significantly to the variation explained by year alone for the proportion of any taxon, as a fraction of either the total sample or the sample minus cod.

\section{Digges Island}

Data were available for Digges Island for five years between 1980 and 1999. In addition, the sample of observations for 1992 was small. Nevertheless, the trends apparent were similar to those seen at Coats Island, with arctic cod comprising $51 \%$ of the diet in 1980-82 and 1992, but only 19\% in 1999 (Table 2), being replaced in 1999 by capelin (up from 7\% in 1980-82 to 41\% in 1999).

\section{DISCUSSION}

Arctic cod decreased as a proportion of thick-billed murre nestling diets at Coats Island from approximately half the items fed to nestlings in the 1980s to less than $20 \%$ from 1997 onwards. A similar tendency was apparent at Digges Island. The fact that the occurrence of zoarcids in the sample without cod was correlated with the proportion of cod in the original sample, and that year had no additional effect on their representation once the effect of the original proportion of cod had been taken into account, suggests that these benthic fish may be taken incidentally by birds that are primarily taking cod. Conversely, the proportion of capelin in the sample without cod was 

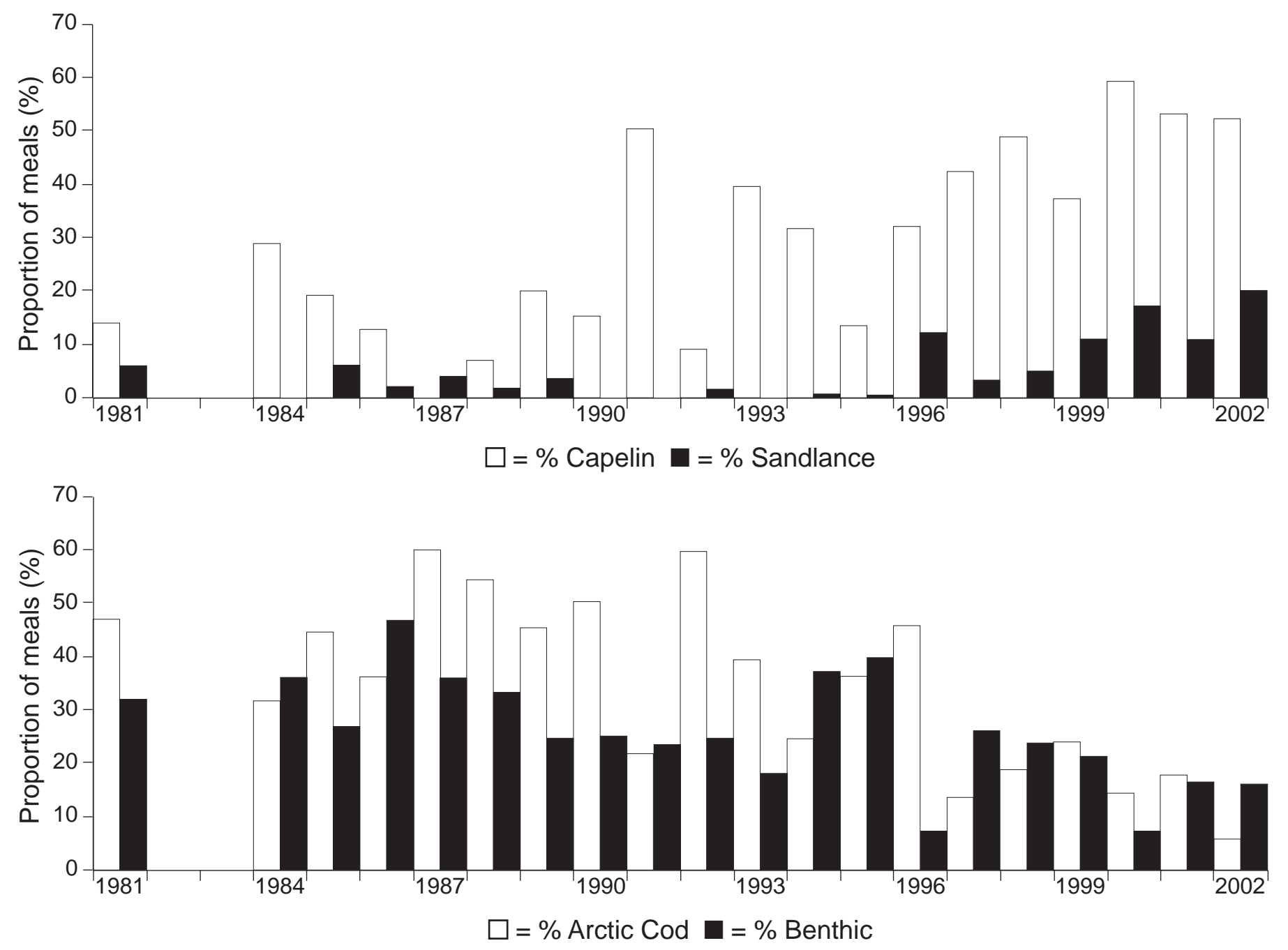

FIG. 2. Proportion of different prey taxa in the diet of nestling thick-billed murres at Coats Island since 1981: a) increasing (capelin and sandlance); b) declining (arctic cod and benthic genera).

negatively correlated with the proportion of cod in the original sample. This fact suggests that the rise in the representation of capelin in the diet was caused not simply by a compensatory switch to capelin, but, at least in part, by a rise in the availability of capelin, which caused the murres to direct their foraging efforts preferentially towards this species.

The observed trends paralleled a decrease in July ice cover in Hudson Bay, which declined from $60000 \mathrm{~km}^{2}$ in the early 1980s to less than $30000 \mathrm{~km}^{2}$ from 1997 on. Satellite microwave observations over the past two decades suggest an increase in the length of the open-water period in Evans Strait from approximately 90 days in 1979 to approximately 130 days in 1996 (Parkinson, 2000). The arctic cod is strongly associated with sea ice throughout its range and makes use of the underside of ice for foraging and to escape from predators (Craig et al., 1982; Sekerak, 1982). It seems likely that a decrease in seasonal ice cover would have adverse effects on arctic cod populations.

Compared to arctic cod, capelin and sandlance are more typical of Subarctic waters (Winters and Carscadden,
1978), where they constitute the most important prey items for the common murre Uria aalge and razorbill Alca torda (Bradstreet and Brown, 1985; Gaston and Jones, 1998), both underwater pursuit divers, like the thick-billed murre. The capelin is sensitive to changes in oceanographic conditions and, in response to fluctuations in water temperatures, has undergone major changes in populations and distribution in waters off Atlantic Canada since the 1980s (Frank et al., 1996; Bryant et al., 1999; Carscadden et al., 2001). Coincidentally, razorbills, previously absent from northern Hudson Bay, were showing signs of colonizing Coats Island in 2001 and 2002 (K. Woo and A.J. Gaston, unpubl. data).

If arctic cod occur mainly near ice, it could be argued that their decrease in the diet of thick-billed murres at Coats Island is the result of a reduction in their availability, rather than their abundance. However, two lines of evidence indicate otherwise. Firstly, at High Arctic colonies, where thick-billed murres feed their chicks mainly on arctic cod, they do so in some years well after ice has cleared away from adjacent waters (Birkhead and 
TABLE 2. Representation of different prey taxa (\% meals delivered) in nestling diets at Digges Island (contingency table, $\left.\chi_{10}^{2}=89.8, p<0.001\right)$.

\begin{tabular}{lccc}
\hline \hline & $1980-82$ & 1992 & 1999 \\
\hline $\mathrm{N}$ & 194 & 35 & 122 \\
Cod & 51.5 & 51.4 & 18.9 \\
Capelin & 6.7 & 17.1 & 41.0 \\
Sandlance & 13.9 & 2.9 & 13.9 \\
Zoarcid & 14.4 & 17.1 & 13.9 \\
Sculpin & 4.6 & 11.4 & 6.6 \\
Others & 8.8 & 0 & 5.7 \\
\hline \hline
\end{tabular}

Nettleship, 1981; Gaston and Nettleship, 1981). This suggests that cod remain available to murres even after ice has retreated. Secondly, 2002 was a late year for ice in northern Hudson Bay, with the extent in mid-June similar to that seen in 1992, the year of the Mount Pinatubo eruption (Canadian Ice Service, 1981-2002). Despite the late ice breakup, the proportion of arctic cod recorded at Coats Island in 2002 was the lowest of any year, suggesting that the late breakup had no effect in making cod more available. We conclude that the trends we observed related to real changes in fish populations, rather than simply reflecting changes in the accessibility of the fish to murres.

Recent studies of foraging behaviour of thick-billed murres at Coats Island (Woo et al., unpubl. data) suggested that most fish delivered to nestlings were caught within $100 \mathrm{~km}$ of the colony. Hence, the main foraging zone during the nestling period falls within the relatively small area of greatly increased open water season apparent on Parkinson's (2000) microwave images. Given the relative ecology of arctic cod and capelin, the trends that we have identified seem best explained by changes in the oceanography of northern Hudson Bay, perhaps driven by temperature increases over recent decades. Our evidence from the diet of nestling thick-billed murres suggests that a switch from an Arctic to a Subarctic fish community occurred from 1997 onwards. As there is no commercial fishery in the area, there is no ongoing fisheries research that could provide this information. In this instance, the seabirds have provided us with evidence that was not otherwise accessible.

\section{ACKNOWLEDGEMENTS}

Thanks to all the many individuals who participated in observations of food delivered at Coats and Digges Islands over the past two decades: special thanks to Richard Elliot, Kerstin Kober, Kara Lefevre, Dave Noble, Paul Smith, and Uli Steiner for their contributions to the field work. We are most grateful to D. McAllister, B. Coad, and C. Renaud of the Canadian Museum of Nature for the identification of voucher specimens, and to C. Renaud for general advice on fish identification and taxonomy. Thanks also to the staff of the Science Institute of the Northwest Territories, and to the Polar Continental Shelf Project of Natural Resources Canada, for providing

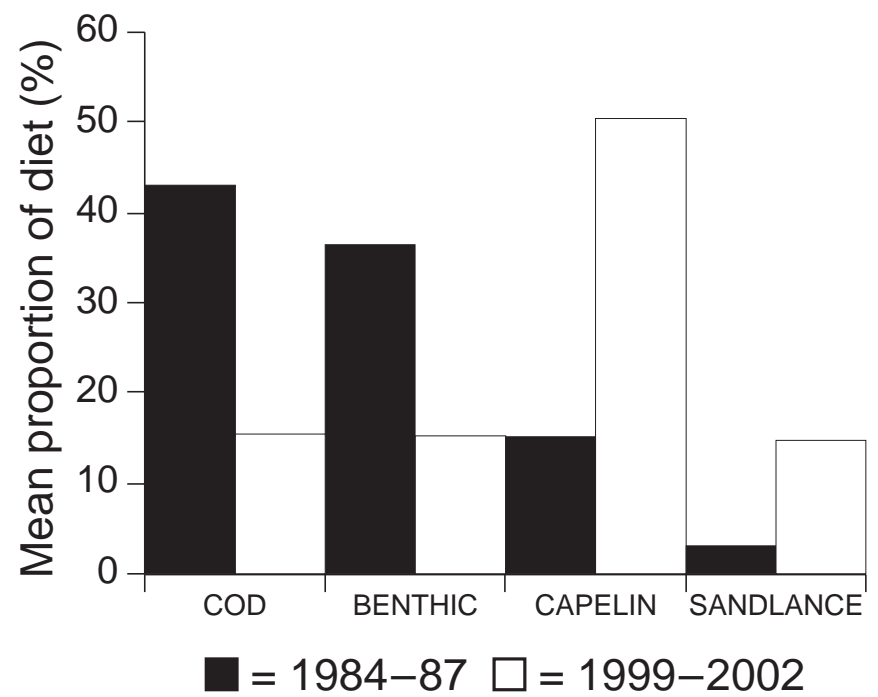

FIG. 3. Proportion of prey types delivered to chicks in 1984-1987 and 19992002 (benthic $=$ sculpins + zoarcids). Values are means of annual proportions. Two-tailed t-tests comparing periods: $\mathrm{Cod}, \mathrm{t}=3.8$; benthic, $\mathrm{t}=4.2$; capelin, $\mathrm{t}=-4.6$; sandlance, $\mathrm{t}=-4.4 ;$ all $\mathrm{df}=6$, all $p<0.01$.

logistical support to our field camp. We thank the Canadian Ice Service for making available the data on ice cover in Hudson Bay over the past three decades. Funding for this research came from the Canadian Wildlife Service, the Natural Sciences and Engineering Research Council of Canada, and the Northern Studies Training Program. Christine Eberl drew the map. Earlier drafts benefited from the comments of Peter Blancher, Hugh Boyd, Brian Collins, and Grant Gilchrist.

\section{REFERENCES}

BERTRAM, D.F., and KAISER, G.W. 1993. Rhinoceros auklet (Cerorhinca monocerata) nestling diet may gauge Pacific sand lance (Ammodytes hexapterus) recruitment. Canadian Journal of Fisheries and Aquatic Sciences 50:1908-1915.

BIRKHEAD, T.R., and NETTLESHIP, D.N. 1981. Reproductive biology of thick-billed murres Uria lomvia: An inter-colony comparison. Auk 98:258-269.

BOERSMA, P.D. 1978. Galápagos penguins as indicators of oceanographic conditions. Science 200:1481-1483.

BOYD, H., and DIAMOND, A.W. 1994. Influence of climate on Arctic migratory birds. In: Riewe, R., and Oakes, J., eds. Biological implications of global change: Northern perspectives. Jasper, Alberta: Canadian Circumpolar Institute. 67-75.

BOYD, H., and MADSEN, J. 1997. Impacts of global change on Arctic-breeding bird populations and migration. In: Oechel, W.C., Callaghan, T., Gilmanov, T., Holten, J.I., Maxwell, D., Molau, U., and Sveinbjornsson, S., eds. Global change and Arctic terrestrial ecosystems. New York: Springer. 201-217.

BRADLEY, N.L., LEOPOLD, A.C., ROSS, J., and HUFFAKER., W. 1999. Phenological changes reflect climate change in Wisconsin. Proceedings of the National Academy of Sciences 96:9701-9704.

BRADSTREET, M.S.W., and BROWN, R.G.B. 1985. Feeding ecology of the Atlantic Alcidae. In: Nettleship, D.N., and 
Birkhead, T.R., eds. The Atlantic Alcidae. London: Academic Press. 262-318.

BROWN, J.L., LI, S.-H., and BHAGARBATI, N. 1999. Long-term trend toward earlier breeding in an American bird: A response to global warming? Proceedings of the National Academy of Sciences 96:5565-5569.

BROWN, R.G.B. 1991. Marine birds and climatic warming in the northwest Atlantic. In: Montevecchi, W.A., and Gaston, A.J., eds. Studies of high latitude seabirds. 1. Behavioural, energetic and oceanographic aspects of seabird feeding ecology. Canadian Wildlife Service Occasional Paper No. 68. Ottawa: Canadian Wildlife Service. 49-54.

BRYANT, R., JONES, I.L., and HIPFNER, J.M. 1999. Responses to changes in prey availability by common and thick-billed murres at the Gannet Islands, Labrador. Canadian Journal of Zoology 77:1278-1287.

CAIRNS, D.K. 1992. Bridging the gap between ornithology and fisheries science: Use of seabird data in stock assessment models. Condor 94:811-824.

CANADIAN ICE SERVICE. 1981-2002. Ice Archive. http:// europa.cis.ec.gc.ca/CISDataSCGDonnees/ReviewEtude/ ReviewEtude.asp. Accessed 20 September 2002.

CARSCADDEN, J.E., FRANK, K.T., and LEGGETT, W.C. 2001. Ecosystem changes and the effects on capelin (Mallotus villosus), a major forage species. Canadian Journal of Fisheries and Aquatic Sciences 58:73-85.

CATTLE, H., and CROSSLEY, J. 1996. Modelling Arctic climate change. In: Wadhams, P., Dowdeswell, J.A., and Schofield, A.N., eds. The Arctic and environmental change. Amsterdam: Gordon and Breach. 1-12.

CRAIG, P.C., GRIFFITHS, W.B., HALDORSON, L., and McELDERRY, H. 1982. Ecological studies of arctic cod (Boreogadus saida) in Beaufort Sea coastal waters, Alaska. Canadian Journal of Fisheries and Aquatic Sciences 39: 395-406.

CRICK, H.Q.P., and SPARKS, T.H. 1999. Climate change related to egg-laying trends. Nature 399:423 - 424.

CROLL, D.A., GASTON, A.J., BURGER, A.E., and KONNOFF, D. 1992. Foraging behavior and physiological adaptation for diving in thick-billed murres. Ecology 73:344-356.

FALK, K., BENVENUTI, S., DALL'ANTONIA, L., KAMPP, K., and ROBILINI, A. 2000. Time allocation and foraging behaviour of chick-rearing Brünnich's guillemots Uria lomvia in higharctic Greenland. Ibis 142:82-92.

FRANK, K.T., CARSCADDEN, J.E., and SIMON, J.E. 1996. Recent excursions of capelin (Mallotus villosus) to the Scotian Shelf and Flemish Cap during anomalous hydrographic conditions. Canadian Journal of Fisheries and Aquatic Sciences 53:1473-1486.

GANTER, B., and BOYD, H. 2000. A tropical volcano, high predation pressure, and the breeding biology of arctic waterbirds: A circumpolar review of breeding failure in the summer of 1992. Arctic 53:289-305.

GASTON, A.J., and BRADSTREET, M.S.W. 1993. Intercolony differences in the summer diet of thick-billed murres in the eastern Canadian Arctic. Canadian Journal of Zoology 71: $1831-1840$.
GASTON, A.J., and HIPFNER, J.M. 1998. The effect of ice conditions in northern Hudson Bay on breeding by thick-billed murres (Uria lomvia). Canadian Journal of Zoology 76: $480-492$.

- 2000. Thick-billed murre Uria lomvia. In: Poole, A., and Gill, F., eds. The birds of North America, No. 497. Philadelphia: The Birds of North America, Inc.

GASTON, A.J., and JONES, I.L. 1998. The auks. Oxford: Oxford University Press.

GASTON, A.J., and NETTLESHIP, D.N. 1981. The thick-billed murres of Prince Leopold Island. Canadian Wildlife Service Monograph No 6.

GASTON, A.J., CAIRNS, D.K., ELLIOT, R.D., and NOBLE, D.G. 1985. A natural history of Digges Sound. Canadian Wildlife Service Report Series No. 46.

GASTON, A.J., DE FOREST, L.N., GILCHRIST, H.G., and NETTLESHIP, D.N. 1993. Monitoring thick-billed murre populations at colonies in northern Hudson Bay, 1972-1992. Canadian Wildlife Service Occasional Paper 80:1-13.

GASTON, A.J., DE FOREST, L.N., DONALDSON, G., and NOBLE, D.G. 1994. Population parameters of thick-billed murres at Coats Island, Northwest Territories, Canada. Condor 96:935-948.

HAMER, K.C., MONAGHAN, P., UTTLEY, J.D., WALTON, P., and BURNS, M.D. 1993. The influence of food supply on the breeding ecology of kittiwakes Rissa tridactyla in Shetland. Ibis 135:255-263.

HUGHES, L. 2000. Biological consequences of global warming: Is the signal already apparent? Trends in Ecology and Evolution 15:56-61.

HUNTER, J.G., LEACH, S.T., McAlLISTER, D.E., and STEIGERWALD, M.B. 1984. A distributional atlas of the records of marine fishes of Arctic Canada in the National Museums of Canada and Arctic Biological Station. Syllogeus $52: 1-35$.

INOUYE, D.W., BARR, B., ARMITAGE, K.B., and INOUYE, B.D. 2000. Climate change is affecting altitudinal migrants and hibernating species. Proceedings of the National Academy of Sciences 97:1630-1633.

INTERGOVERNMENTAL PANEL ON CLIMATE CHANGE. 1995. Climate change 1995 - The science of climate change: Contribution of Working Group I to the Second Assessment Report of the Intergovernmental Panel on Climate Change. Houghton, J.T., Meira Filho, L.G., Callander, B.A., Harris, N., Kattenberg, N., and Maskell, K., eds. Cambridge: Cambridge University Press.

LEDREW, E.F. 1993. Climate variability, change and sensitivity. In: French, H.M., and Slaymaker, O., eds. Canada's cold environments. Montreal and Kingston: McGill-Queen's University Press. 271-290.

McCORMICK, M.P., THOMASON, L.W., and TREPTE, C.R. 1995. Atmospheric effects of the Mt. Pinatubo eruption. Nature 373:399-404.

MONTEVECCHI, W.A. 1993. Birds as indicators of change in marine prey stocks. In: Furness, R.W., and Greenwood, J.J.D., eds. Birds as monitors of environmental change. New York: Chapman and Hall. 217-266. 
MONTEVECCHI, W.A., and MYERS, R.A. 1996. Dietary changes of seabirds indicate shifts in pelagic food webs. Sarsia 80: $313-322$.

1997. Centurial and decadal oceanographic influences on changes in northern gannet populations and diets in the northwest Atlantic: Implications for climate change. International Council for the Exploration of the Sea (ICES) Journal of Marine Science 54:608-614.

PARKINSON, C.L. 2000. Variability of Arctic sea-ice: The view from space, an 18-year record. Arctic 53:341-358.

SEKERAK, A.D. 1982. Young-of-the-year cod (Boreogadus) in Lancaster Sound and western Baffin Bay. Arctic 35:75-87.

STATSOFT INC. 2001. STATISTICA for Windows 6.0. Tulsa, Oklahoma: Statsoft Inc.

STIRLING, I., LUNN, N.J., and IACOZZA, J. 1999. Long-term trends in the population ecology of polar bears in western
Hudson Bay in relation to climatic change. Arctic 52:294-306. TUCK, L.M. 1961. The murres. Canadian Wildlife Service Monograph No 1. Ottawa: Canadian Wildlife Service.

UTTLEY, J., MONAGHAN, P., and WHITE, S. 1989. Differential effects of reduced sandeel availability on two sympatrically breeding species of tern. Ornis Scandinavica 20:273-277.

VINNIKOV, K.Y., ROBOCK, A., STOUFFER, R.J., WALSH, J.E., PARKINSON, C.L., CAVALIERI, D.J., MITCHELL, J.F.B., GARRETT, D., and ZAKHAROV, V.F. 1999. Global warming and Northern Hemisphere sea ice extent. Science 286:1934-1937.

WINTERS, G.H., and CARSCADDEN, J.E. 1978. Review of capelin ecology and estimation of surplus yield from predator dynamics. International Commission for the Northwest Atlantic Fisheries (ICNAF) Research Bulletin13:21-30. 